\title{
Grand Jury Proceedings: The Prosecutor, the Trial Judge, and Undue Influence
}

The value of the grand jury system has been intensely debated for more than a century. ${ }^{1}$ While its champions consider it a shield against state oppression and an essential element in our constitutional system, ${ }^{2}$ it has been attacked as archaic, inordinately cumbersome and expensive, and a tool of prosecutorial oppression. ${ }^{3}$ Whatever the relative merits of these arguments, the grand jury remains an important part of our criminal justice system. ${ }^{4}$ In the federal system and in more than half of the states, no person may be charged with commission of a felony except by indictment returned by a legally constituted grand jury. ${ }^{5}$ In most other states, the prosecutor has discretion either to seek a grand jury indictment or to commence a felony prosecution directly by filing an information. ${ }^{8}$ In the latter jurisdictions, although the number of prosecutions initiated by indictment is small, ${ }^{7}$ prosecutors often call

1 See, e.g., J. Bentham, The Elements of Packing as Applied to Spectat Juries 26 (1821); 2 J. Bentham, Rationale of Judicial Evidence 312-14 (1827); R. Younger, The People's Panel: The Grand Jury in the United States, 1634-1941 (1963); 1 National Comm'n on Law Observance and Enforcement, Report on Prosecution No. 4, at 34-37 (1931) [hereinafter cited as WICKERSHAM COMMISSION REPORT]; Calkins, Abolition of the Grand Jury Indictment in Illinois, 1966 LLL. L.F. 423 (1966); Dession, From Indictment to Information-Implications of the Shift, 42 YALE L.J. 163 (1932); Friedman, Strange Doings by the "Honest Countrymen," N.Y. Times, Nov. 7, 1971, § 4, at 8; Kranjitz, The Grand Jury: Past-Present-No Future, 24 Mo. L. Rev. 318 (1959); Kuh, The Grand Jury "Presentment": Foul Blow or Fair Play?, 55 Colum. L. Rev. 1103 (1955); Mar, The California Grand Jury System: A Vestige of Aristocracy, I PAc. L.J. 36 (1970); Moley, The Institution of Criminal Prosecutions by Indictment or Information, 29 МICH. L. REv. 403 (193I); Tigar \& Levy, The Grand Jury as the New Inquisition, 50 MICH. ST. B.J. 693 (1971); Watts, Grand Jury: Sleeping Watchdog or Expensive Antique?, 37 N.C.L. REv. 290 (1959); Whyte, Is the Grand Jury Necessary?, 45 VA. L. REv. 461 (1959); Younger, The Grand Jury Under Attack, 46 J. Crm. L.C. \& P.S. 26 (1955); Note, Should the Grand Jury System Be Abolished?, $45 \mathrm{KY}$. L.J. 151 (1967).

2 See Judge James Alger Fee's defense of the system in United States v. Smyth, 104 F. Supp. 283 (N.D. Cal. 1952).

8 See, e.g., 2 J. Bentham, Rationale of Judictal Evidence 312-14 (1827); Whyte, supra note 1 , at $488-91$.

4 The grand jury system has been abolished in England. Administration of Justice (Miscellaneous Provisions) Act of 1933, 23 \& 24 Geo. 5, c. 36.

5 See Calkins, supra note 1, at 424; Spain, The Grand Jury, Past and Present: A Survey, 2 AM. CrIM. L.Q. 119, 126-42 (1964); Note, An Examination of the Grand Jury in New York, 2 Colum. J.L. \& Soc. Prob. 88, 90 (1966).

6 See, e.g., CaL. Penal Code § 913 (Deering 1971). See also authorities cited note 5 supra. T Moley, supra note 1, at 412-13. In addition to Moley's work, only one other major 
grand juries in instances of particular community interest and importance. ${ }^{8}$

Because the grand jury is generally thought to be a safeguard against unwarranted criminal charges, grand jury indictment has a more serious impact on the accused than does accusation by information. While a state's prosecutor acting alone may be suspected of political or personal motives, the public generally gives greater credence to the pronouncements of the grand jury, whose members are drawn from-and presumably represent-the community. ${ }^{9}$ Whatever the final outcome of his case may be, indictment can cause the accused loss of employment, lessening of community respect, and an expensive, time-consuming legal battle.

Despite the serious effects an indictment can have, the grand jury operates by means of secret, ex parte procedures, without the internal checks of open, adversary procedures. ${ }^{10}$ The roles played by the prosecutor and trial judge in the operation of the system are therefore particularly important. The statutes governing the grand jury fail, however, to define these roles clearly. ${ }^{11}$ Although the case law is somewhat more enlightening, the courts have not scrutinized the functions of the prosecutor and the trial judge in grand jury proceedings with the same thoroughness that has characterized their recent reappraisal of other elements of pretrial procedure. ${ }^{12}$ This comment examines the proper

empirical study of the grand jury process has been made. See Morse, $A$ Survey of the Grand Jury System (pts. 1-3), 10 ORE. L. REv. 101, 217, 295 (1931).

8 Id. For an example of this phenomenon, see Beck v. Washington, 369 U.S. 541 (1962) (investigation of allegedly corrupt Teamsters Union president).

$\because$ Note, Discretionary Power in the Judiciary to Organize a Special Investigatory Grand Jury, 111 U. PA. L. REv. 954, 955 (1963); see R. YoungER, supra note 1. The method of selecting grand jurors varies by jurisdiction. The prevalent method of selection is the "objective" method, by which grand jurors are chosen by lot from voter lists or tax roles. In a few states, however, a judge or other official has discretionary power to choose grand jurors. Spain, supra note 5, at 121, 126-42. One commentator has argued that discretionary selection leads, de facto, to an unrepresentative grand jury panel. Mar, supra note 1.

10 For a discussion of the benefits of open adversary procedures, see K.C. DAvis, ADMinisTRATIVE LAW TExT \$\$ 406, 704 (3d ed. 1972).

11 The grand jury is still very much a creature of the common law. Costello v. United States, 350 U.S. 359, 362 (1956). The federal statutes say almost nothing about the proper roles of the prosecutor and the judge in grand jury proceedings. See FED. R. CRIM. P. 6. Even those states that have enacted fairly elaborate guidelines for grand jury practice generally fail to define fully the proper functions of the trial judge and the prosecutor. See, e.g., Cal. Penal Code §§ 888-939.3 (Deering 1971); N.Y. Code Crim. Proc. § 190.05-.90 (McKinney 1971).

12 Hutardo v. California, 110 U.S. 516 (1884), remains good authority for the proposition that the fifth amendment requirement of felony prosecution by indictment does not apply to the states. Although the Supreme Court has applied stringent defendant protections at other critical pretrial stages, e.g., Miranda v. Arizona, 384 U.S. 436 (1966), it has sought to keep the grand jury procedure as free from "technical" requirements as possible, e.g., 
functions of the prosecutor and the trial judge in grand jury proceedings, with particular attention, first, to the standards that govern their conduct in performing these functions, and, second, to the judicial response to charges that the standards of proper conduct developed by the courts have been breached.

\section{Functions of the Prosecutor and Trial Judge}

\section{A. The Grand Jury}

The roles of the prosecutor and the trial judge can be understood only in relation to the general function of the grand jury. Historically, the grand jury ${ }^{13}$ has had three basic functions: ${ }^{14}$ (1) investigating within the boundaries of the community any "public offenses"15 that may have been committed; (2) determining who is responsible for an offense and deciding whether there is probable cause to charge him with the commission of a crime; and (3) making its findings public in an appropriate tribunal by submitting an indictment, presentment, or report. ${ }^{10}$

Although the grand jury retains the legal authority to perform these functions, ${ }^{17}$ the manner in which it exercises its authority has changed

Costello v. United States, 350 U.S. 359, 363 (1956). Indeed, the Court has given the grand jury "special treatment," cf. Jenkins v. McKeithen, 395 U.S. 411, 430-31 (1969), permitting it to interrogate a potential defendant without the right to counsel, the right to present evidence, to cross-examine witnesses, or to know the evidence against him.

13 The number of grand jurors varies from jurisdiction to jurisdiction although in no state is the number greater than twenty-three. Only one state requires a unanimous vote to indict; most states require only a simple majority. Spain, supra note 5, at 122, 126-142.

14 Some commentators have divided the grand jury's functions into two general categories, investigatory and accusatory. For an institutional history of the grand jury system, see 4 Blackstone, Commentaries on the Laws of England 301-07 (Tucker ed. 1803); G. EDWARDS, THE GRAND JURY (1906); R. YOUNGER, supra note 1; Kuh, supra note 1, at 1105-10; Orfield, The Federal Grand Jury, 22 F.R.D. 343 (1958); Whyte, supra note 1, at 462-82.

15 Early grand juries often inquired into noncriminal activities that offended the public's conscience, as well as strictly criminal activity. $R$. YoungER, supra note 1, at 13-18.

16 In early grand jury practice there was a distinction made between a presentment and an indictment. An indictment was a written "bill" submitted by the prosecutor to the grand jury charging someone with a crime or specifying matters to be investigated. The grand jury would then consider the prosecutor's bill and vote either a "true bill" or a "no bill," thereby accepting or rejecting the prosecutor's accusation. A presentment was a bill returned by the grand jury itself, based upon facts that came to its knowledge from someone other than the king's representative. Since the prosecutor has been allowed into the grand jury room, this traditional distinction has often been overlooked. Written statements that accompany formal accusations or are submitted separately have become known as grand jury reports, whether they are inserted at the suggestion of the prosecutor or the grand jurors. This comment refers to any formal charge of criminal behavior that results from a grand jury investigation as an indictment. The term "report" includes any statement that accompanies the charge or that the grand jury submits separately. See United States v. Cox, 342 F.2d 167, 187-89 (5th Cir. 1965) (Wisdom, J., concurring), cert. denied, 381 U.S. 822 (1965); Kuh, supra note 1.

17 In re Grand Jury January, 1969, 315 F. Supp. 662, 671 (D. Md. 1970). 
significantly in response to the exigencies of modern society. In the past, the grand jury often combed the community to uncover reprehensible activity, decided the scope and direction of its investigations, and issued general statements and findings concerning political and social questions. But grand jurors today lack the intimate knowledge of community activity possessed by grand jurors of preurban society. They also lack the investigative tools now necessary to find evidence of crime. Allowing professional investigative agencies to gather relevant facts and present them to the grand jury through the prosecutor has increased efficiency in investigation and decision making. ${ }^{18}$ At the same time, however, it has made the modern grand jury a generally more passive instrument than its precursors. Grand juries now conduct their investigations almost exclusively within the confines of the grand jury room, ${ }^{19}$ rely almost entirely on the prosecutor to determine the subject matter and general direction of the investigation, ${ }^{20}$ and seldom issue documents unrelated to some specific criminal activity or malfeasance in office. ${ }^{21}$

The relative decline in importance of the grand jury as an independent investigative body underscores the continued importance of its remaining function: determining probable cause. ${ }^{22}$ The grand jury's in-

18 WiCkERShaM CoMmission Reporr, supra note 1 , at 36.

19 Modern grand juries occasionally embark on "field trips" to investigate conditions at county jails or other state run institutions. These excursions are, however, the exception rather than the rule. See, e.g., CAL. PENAL Code \$ 919(b) (Deering 1971) (charging the grand jury with the duty to inquire into the condition and management of public persons).

20 WIGKERSham CoMmission REPORT, supra note 1, at 36-37; Calkins, supra note 1, at 431.

21 Younger points out that in the past grand jury reports served as important expressions of community sentiment since grand jurors were permitted to report on any matters that seemed appropriate, including matters of general community and social interest as broad as a discourse on the revolutionary war and as narrow as the personal lives of local townspeople. See generally R. Younger, supra note 1. Modern courts have restricted the grand jury's authority to make reports by expunging all deleterious references to private individuals who have not been formally accused of criminal behavior. Some courts have extended this protection to public officials. E.g., State ex rel. Brautigan v. Interim Report of Grand Jury, 93 So. 2d 99, 102 (S. Ct. Fla. 1957). Others hold that public officials may be singled out for misconduct in office. E.g., In re Essex County Grand Jury, 110 N.J. Super. 24, 264 A.2d 653 (N.J. 1970). Although some federal courts have disapproved of grand jury reports that condemn, commend, or make recommendations concerning the operations of public boards or authorities. Hammond v. Brown, 323 F. Supp. 326, 345 (N.D. Ohio), aff'd, 450 F.2d 480 (6th Cir. 1971), Kuh points out that several jurisdictions take the view that the grand jury should be allowed to report on malfeasance or nonfeasance in local governmental bodies. Kuh, supra note 1 , at 1114 .

22 An exception to this may be the so called special investigatory grand jury typically led by a court-appointed "special prosecutor" to uncover political corruption. Some commentators feel that these bodies are extremely effective adjuncts to the state's Iaw enforce. ment machinery. See Note, The Grand Jury as an Investigatory Body, 74 HARv. L. REv. 
dependent judgment of probable cause serves as a basic check on prosecutorial discretion. Although there are agencies better able to detect crimes and to accuse individuals of having committed them, the grand jury is the only institution that can shield one wrongfully accused from the power of the state to bring individuals to trial. ${ }^{23}$

\section{B. The Prosecutor}

The modern prosecutor plays two sometimes inconsistent roles in grand jury proceedings. ${ }^{24}$ As an officer of the state, he must exert his best efforts to prosecute successfully those who have violated the criminal laws. As an officer of the court, he is required to act as the grand jury's legal advisor, to aid, but not direct, its determination of probable cause. ${ }^{25}$ This dichotomy requires the prosecutor to make his own determination as to probable cause, but at the same time requires that he avoid compelling the grand jury to accept his conclusion.

In the usual case, where the prosecutor has concluded that there is probable cause before he submits the case to the grand jury, ${ }^{26}$ the prosecutor's dual role creates an inherent conflict of interest. As legal advisor to the grand jury, the prosecutor advises the members on points of law, helps to insure that the proceedings are conducted in an orderly fashion, and aids the grand jury in obtaining all the evidence it needs to make an informed judgment. ${ }^{27}$ As the state's prosecutor, with the duty to prosecute those who he believes have committed crimes, he may present or select the evidence in a manner designed to influence the grand jury to agree with his view of the case. ${ }^{28}$ As a practical matter,

590 (1961); Note, Discretionary Power in the Judiciary To Organize a Special Investigating Grand Jury, 111 U. PA. L. REv. 954 (1963). However, it has been argued that if the special prosecutor is a government lawyer rather than a neutral lawyer-citizen, the special grand jury may become an oppressive inquisition. See Tigar \& Levy, supra note 1.

$23 \mathrm{R}$. Youncer, supra note $\mathrm{I}$, at 3 . In an unusual case the prosecutor may serve as a check on the grand jury's power to indict if he feels that the grand jury has wrongfully accused an individual of criminal behavior. In most state courts the prosecutor can request the judge to nolle prosequi the indictment. In the federal courts he can simply refuse to sign the indictment, thereby automatically insulating an accused from prosecution. See United States v. Cox, 342 F.2d 167 (5th Gir. 1965), cert. denied, 381 U.S. 822 (1965); In re Grand Jury January, 1969, 315 F. Supp. 622 (D. Md. 1970).

24 Under English common law the attorney for the crown was not permitted to enter the grand jury room at any time during the grand jury proceedings. G. EDwards, supra note 14 , at 127 . In addition, the early prosecutor had a single role-to represent the crown. He had no duty to advise or aid the grand jurors.

25 See Hammers v. State, 337 P.2d 1097, 1106-07 (Okla. Crim. App. 1959).

26 Cf. Moley, supra note 1, at 414-15; Morse, supra note 7, at 362.

27 Interview with Robert Coleman, Assistant Attorney General of Illinois, in Chicago, Apr. 26, 1972.

28 Most states allow the prosecutor to present any evidence to the grand jury that he believes appropriate. See, e.g., ILL. REV. STAT. ch. 38, § 112-4(a) (1971). 
he is likely to be more strongly motivated by his duty to bring people to trial than by his duty to advise the grand jury impartially. Consequently, the prosecutor may press for the result he desires so strongly that the grand jury may be unable to make an intelligent, independent determination of probable cause and becomes simply a "rubber stamp" of the prosecutor. ${ }^{29}$

Several factors have persuaded the courts to countenance this conflict of interest and, hence, to allow the prosecutor to participate in the proceedings: (1) the necessity of providing the grand jury with professional legal advice, without the inefficiency and cost of allowing it to hire its own attorney;30 (2) the need to rely on the investigative agencies of the state; and (3) a desire to protect the state's interest in prosecuting crime. The courts have attempted, however, to establish rules of conduct that allow the prosecutor to transmit the state's view of the case to the grand jury but, at the same time, prevent him from overpowering the grand jury with his skills as an advocate. Under this scheme, the prosecutor has the power to influence the direction of the proceedings, but the grand jury retains the power to refuse to indict. ${ }^{31}$

The prosecutor generally initiates the proceedings and determines the scope of the inquiry by requesting the judge to impanel a grand jury for stated purposes. ${ }^{32}$ If a grand jury has already been impaneled, the prosecutor may request that it be called into session. ${ }^{33} \mathrm{He}$ is allowed to be present in the grand jury room at all times during the investigative stage of the proceedings, ${ }^{34}$ and may call any witness and offer any

29 Opponents of the grand jury system argue that even with the safeguards afforded by the undue influence doctrine, the prosecutor's participation in the proceedings necessarily reduces the grand jury to a rubber stamp. See, e.g., Calkins, supra note 1, at 432-33; Moley, supra note 1, at 414-15; Tigar \& Levy, supra note 1. Although there is some statistical evidence to support this view, Morse, supra note 1, at 362, its validity has been disputed, R. YoUNGER, supra note 1 , at 229-232.

30 On occasion, special investigatory grand juries may be allowed to draw on the public treasury to retain a private attorney appointed by the court. See Note, supra note 9 , at 971-73. But it is apparently thought that allowing the normal grand jury to hire its own attorney would be a needless duplication of the prosecutor's function. See Calkins, supra note 1 , at 436 .

31 A prosecutor who has been "no billed" by the grand jury or who has had an indictment quashed by the trial judge may call a new grand jury to seek reindictment. Several factors, however, militate against seeking reindictment. A "no bill" indicates that the prosecutor's case is probably too weak to go to trial, where the burden of proof is much greater. If an indictment has been quashed because of undue influence, public sentiment may deter an attempt to reindict. Finally, the statute of limitations may prevent reindictment in some cases.

32 Moley, supra note 1, at 414; cf. Morse, supra note 7, at 140.

33 D. Mernitz, A Practical handbook of Federal Grand Jury Procedure § 2:1 (1968).

34 See, e.g., N.Y. CoDe CRrM. Proc. § 190.25 (McKinney 1971). The investigative stage runs from the beginning of the proceedings until the grand jury begins to deliberate and to vote on the indictment. 
documentary evidence he thinks pertinent. ${ }^{35}$ The prosecutor may grant immunity to prospective witnesses ${ }^{36}$ and conduct the examination of any witness called. He may advise the grand jury on the technical requirements for finding probable cause and may offer indictments charging specific individuals with particular crimes. ${ }^{37}$

The powers of the grand jurors counterbalance and complement those of the prosecutor. Grand jurors may extend or broaden the scope of the investigation, call for the production of witnesses and documents, question witnesses, and request legal advice from both the prosecutor and the judge..$^{38}$ The power of the grand jury relative to that of the prosecutor is augmented by forbidding the prosecutor to comment on the weight or sufficiency of the evidence ${ }^{39}$ and by barring him from the grand jury room during the actual deliberations and voting. ${ }^{40}$

\section{The Trial Judge}

The grand jury is an "arm of the court," dependent on the use of the court's process to enforce its directives; ${ }^{41}$ and the trial judge has the responsibility to ensure that those subjected to the process will not be harmed unfairly by an overzealous prosecutor or grand jury. Because of the peculiar nature of grand jury procedures, however, the trial judge may have more difficulty in insuring fairness than he does in other judicial contexts. He is barred from the grand jury room throughout the proceedings, ${ }^{42}$ and thus cannot obtain firsthand information about them. In addition, the nonadversary nature of the procedure often denies the judge the important balancing view, both legal and factual, ordinarily provided by defense attorneys. ${ }^{43}$

35 See note 28 supra.

30 See D. MERnITz, supra note 33 , at $\S 4: 3$.

37 G. EDWARDs, supra note 14, at 129.

38 United States v. Smyth, 104 F. Supp. 283 (N.D. Cal. 1952).

39 State v. Good, 10 Ariz. App. 556, 559, 460 P.2d 662, 665 (1969).

40 In most jurisdictions, the presence of the prosecutor in the grand jury room during voting and deliberation is sufficient grounds for quashing an indictment. See Williams v. State, 188 Ind. 283, 302-07, 123 N.E. 209, 216-17 (1919). In some states, however, the defendant must show some improper behavior in addition to mere presence in order to obtain dismissal of the indictment. See Commonwealth v. Beneficial Fin. Co., - Mass. -, 一, 275 N.E. 2d 33, 46-47 (1971), cert. denied, 407 U.S. 914 (1972).

41 In re National Window Glass Workers, 287 F. 219, 224-25 (N.D. Ohio 1922).

42 See, e.g., Hammers v. State, 337 P.2d 1097, 1109-11 (Okla. Crim. App. 1959). Although this rule hinders judgment on motions and pleas, it serves as a strong deterrent to improper judicial conduct. See text at notes 116-18 infra.

43 In extending the right to counsel to the lineup stage of a criminal investigation, the Supreme Court recognized the important function that the defense attorney can perform by detecting possible prejudicial influences during the lineup and by informing the court of these influences at trial. United States v. Wade, 388 U.S. 218, 230-32 (1967). But cf. Kirby v. Ill., 406 U.S. 682 (1972). Similarly, since the defense attorney is barred from 
Despite these difficulties, the judge can exert some measure of control over the prosecutor and the grand jury through his broad, discretionary power over the court's processes. He has the power to order the grand jury into existence; ${ }^{44}$ conversely, unless otherwise provided by statute, ${ }^{45}$ he has complete discretion to refuse to call a grand jury. ${ }^{46} \mathrm{He}$ may dismiss the grand jury "for any cause or for no cause" at any time after it is called. ${ }^{47} \mathrm{He}$ may charge the grand jury as to its duties at the beginning of the investigation, and, upon request of the grand jury, furnish legal advice about matters of law and procedure. ${ }^{48}$ He may deny requests to issue subpoenas duces tecum and ad testificandum ${ }^{49}$ and, after the grand jury submits its findings, he may quash for cause any indictments returned, expunge reports or any surplusage in the indictment, ${ }^{50}$ and divulge the records of the secret grand jury proceedings upon a showing of "particularized need." 51

As a practical matter, perhaps the most important of these powers is the judge's control over the issuance and enforcement of subpoenas. It allows him to maintain a degree of contact with the proceedings and to scrutinize them to a limited extent. But because of traditional restraints against interference with the scope of grand jury investigations, ${ }^{52}$ many trial judges have been hesitant to refuse to issue and enforce subpoenas. ${ }^{53}$ Some appellate courts, however, have recently called for closer

the grand jury proceedings, the court may overlook inferences of prejudice that could have been drawn by a trained defense attorney.

44 Note, supra note 9 , at $960-67$.

45 Some states provide that a grand jury shall be convened a certain minimum number of times per year. See, e.g., Irr. REv. Sxar. ch. 38, \& 112-3(a) (1971).

46 Petition of A. \& H. Transp. Inc., 319 F.2d 69 (4th Cir.), cert. denied, 375 U.S. 924 (1963).

47 Judge Fee's dictum in United States v. Smyth, 104 F. Supp. 283, 292 (N.D. Cal. 1952), has been taken as an indication that the trial judge has absolute, unreviewable discretion to dismiss a grand jury. In re World Arrangements, 107 F. Supp. 628, 629 (D.D.C. 1952). It appears, however, that if a trial judge dismisses a grand jury to shield unjustly a prospective defendant, he may be subject to disciplinary proceedings. State ex rel. Perry v. Livaudias, 201 La. 1083, 11 So. 2 d I (1942); In re Laughlin, 153 Tex. 183, 265 S.W.2d 905, appeal dismissed per stipulation, 348 U.S. 859 (1954).

48 See, e.g., FLA. STAT. AN. § 905.18 (1971).

49 See, e.g., Brown v. United States, 359 U.S. 41, 49-50 (1959), overruled on other grounds, Harris v. United States, 382 U.S. 162 (1965).

50 See authorities cited note 21 supra.

51 Dennis v. United States, 384 U.S. 855 (1966). See Note, Discovery By a Criminal Defendant of His Own Grand-Jury Testimony, 68 Corum. L. Rev. 311 (1968). There are indications that the courts are becoming increasingly liberal in divulging grand jury records. See People v. DiNapoli, 27 N.Y.2d 229, 265 N.E.2d 449, 316 N.Y.S.2d 622 (1970); D. MERNITZ, suppra note 33 , at § 3:4.

52 See United States v. United States District Court, 238 F.2d 713 (4th Gir. 1956), cert. denied, 352 U.S. 981 (1957).

53 See In re April, 1956 Term Grand Jury, 239 F.2d 263 (7th Cir. 1956), vacated on other grounds sub nom., United States v. Shotwell Mfg. Co., 355 U.S. 233 (1957). 
trial court scrutiny of grand jury subpoenas in order to protect first, ${ }^{54}$ fourth, ${ }^{\text {t5 }}$ and fifth ${ }^{56}$ amendment rights.

\section{Judrcial Response to Alteged Misbehavior}

\section{A. The Prosecutor}

1. Undue Influence. Challenges to the validity of grand jury proceedings have primarily involved charges that the prosecutor conducted himself in a manner that subverted the ability of the grand jury to make an independent determination as to probable cause. ${ }^{57}$ The prosecutor's presence in the grand jury room and his active participation in the proceedings must necessarily have some effect on the jurors. The courts have recognized that at some point this influence can become so pervasive that the decision to indict is no longer that of the grand jury but is instead a result dictated by the prosecutor. Rather than attempt the impossible task of examining the motives of each grand juror to determine if the decision to indict was, in fact, independently made, the courts have developed a prophylactic undue influence doctrine that looks to objectively ascertainable prosecutorial behavior. If the prosecutor has engaged in behavior that is likely to have had such a strong effect on the grand jurors that they would have been unable to make an independent judgment, any indictment or report returned by the grand jury will be quashed or expunged regardless of whether the defendant can prove that the prosecutor's behavior did, in fact, result

54 See Branzburg v. Hayes, 408 U.S. 665, 707-08 (1972).

55 See In re Dionisio, 442 F.2d 276 (7th Cir.), cert. dismissed per stipulation, 404 U.S. 878 (1971).

56 See Comment, The Grand Jury Witness Privilege Against Self-Incrimination, 62 Nw. U.L. REv. 207 (1967).

57 Other challenges to the prosecutor's behavior include charges that the prosecutor has abused the court processes by using the broad discovery power of the grand jury for "improper purposes." Prosecutors have, for example, been accused of using the grand jury for political harassment, In re Kinoy, 326 F. Supp. 400 (S.D.N.Y. 1970), to "blackmail" a witness to testify, United States v. Steel, 238 F. Supp. 580 (S.D.N.Y. 1965), and as a discovery device to circumvent the narrower discovery rules of collateral criminal or civil proceedings. Courts that have considered the question of the use of the grand jury as an improper discovery device agree that if the prosecutor's sole or dominating motive in calling an investigation is to obtain evidence for use in collateral proceedings, the prosecutor has abused the court's processes. The burden of proving the prosecutor's "bad faith," however, has been so difficult that "improper purposes" challenges have been successful in only three cases: United States v. Procter \& Gamble Co., 356 U.S. 677 (1957), on remand, 187 F. Supp. 55 (D.N.J. 1960); In re April, 1956 Term Grand Jury, 239 F.2d 253 (7th Cir. 1956), vacated on other grounds sub nom., United States v. Shotwell Mfg. Co., 355 U.S. 233 (1957); In re National Window Glass Workers, 287 F. 219 (N.D. Ohio 1922). See generally In re Grand Jury Investigation, 32 F.R.D. 175, appeal dismissed, 318 F.2d 533 (2d Cir.), cert. dismissed per stipulation, 375 U.S. 802 (1963); United States v. Carter, 27 F.R.D. 243 (S.D.N.Y. 1961); United States v. Pack, 150 F. Supp. 262 (D. Del.), appeal dismissed, 247 F.2d 168 (3d Cir. 1957); Application of Iaconi, 120 F. Supp. 589 (D. Mass. 1954). 
in prejudice..$^{58}$ Examples of prosecutorial behavior that have been the basis for a finding of undue influence include: making pleas, threats, or other coercive statements that may tend to induce the grand jury to indict a particular individual; ${ }^{59}$ expressing any opinion concerning the sufficiency and weight of the evidence, even if requested to do so by the grand jury; ${ }^{60}$ summarizing the evidence; ${ }^{61}$ making inflammatory speeches against individual indictees; ${ }^{62}$ using examination techniques that impugn the character of a prospective defendant; ${ }^{63}$ and, in many jurisdictions, merely being present when the grand jury deliberates and votes. ${ }^{64}$ Although these prohibitions do not affect the influence inherent in a well-prepared case, they free the grand jury from overt prosecutorial pressure to indict.

Although the standards that govern the prosecutor's behavior seem adequate, their enforcement has unfortunately proved somewhat diffcult. The accused who seeks to attack the grand jury's indictment on the basis of undue influence must overcome severe obstacles of discovery and proof. Faced with a strong presumption of the regularity of the proceedings, ${ }^{65}$ the defense attorney must ordinarily be able to point to specific acts and comments of the prosecutor that constitute undue influence. ${ }^{66}$ Since the defense attorney is both barred from the proceedings and denied full access to a transcript of them, ${ }^{67}$ his only sources of information are the witnesses who have appeared before the grand jury and the grand jurors themselves. ${ }^{68}$ Witnesses may, in some cases, be willing to inform the defense attorney of prosecutorial misconduct, but, in many instances, proscribed behavior may have occurred when

58 United States v. Wells, I63 F. 313, 327-29 (D. Idaho 1908).

59 See, e.g., State v. Good, 10 Ariz. App. 556, 400 P.2d 662 (1969), and cases cited therein.

60 See, e.g., Hammers v. State, 337 P.2d 1097, 1106-07 (Okla. Crim. App. 1959), and cases cited therein.

61 E.g., Attorney Gen. v. Pelletier, 240 Mass. 264, 309, 134 N.E. 407, 419 (1922).

62 See, e.g., United States v. Wells, 163 F. 313 (D. Idaho 1908). But cf. United States v. Riccobene, 320 F. Supp. 196 (E.D. Pa. 1970), aff'd, 451 F.2d 586 (3d Cir. 1971).

63 See, e.g., United States v. DiGrazia, 213 F. Supp. 232, 234-35 (N.D. Ill. 1963); Application of United Elec., Radio \& Mach. Workers, 111 F. Supp. 858, 869-70 (S.D.N.Y. 1953).

64 See note 40 supra.

65 United States v. Steel, 238 F. Supp. 580, 582 (S.D.N.Y. 1965).

66 United States v. Mitchell, 136 F. 896, 906-07 (D. Ore.), appeal dismissed per stipulation, 199 U.S. 616 (1905).

67 See authorities cited note 51 supra. A few states, however, have enacted statutes that allow the defendant to obtain a copy of any testimony heard by the grand jury that in dicted him. Note, supra note 51 , at 317.

68 The rules that apply to grand jurors concerning postindictment testimony as to prosecutorial behavior apply as well to court reporters and interpreters (and other nongrand jurors who are allowed to be present in the grand jury room during the proceedings). See authorities cited note 88 infra. 
no witnesses were present. ${ }^{60}$ While the jurors would be invaluable sources, the rules of many jurisdictions effectively prevent the defense attorney from obtaining information from them. In some jurisdictions, grand jurors are absolutely forbidden to give defense attorneys information concerning the prosecutor's behavior; ${ }^{70}$ in others, courts have been reluctant to allow defense attorneys to interview the jurors. ${ }^{71}$

If the defense attorney does manage to discover specific acts of prosecutorial behavior that are proscribed by the undue influence doctrine, he may nevertheless be faced with substantial difficulty in proving his contention. The only evidence available to support the defense attorney's motion may be the transcript of the proceedings and the testimony of witnesses and grand jurors. In some jurisdictions, however, there is an absolute prohibition on the use of grand juror testimonywhether in the form of affidavit or of oral testimony in open court-on the question of undue influence. ${ }^{72}$ Without statements from grand jurors, the undue influence doctrine may be unenforceable, particularly in cases in which no witness was present when the prohibited act occurred and in jurisdictions in which transcripts of grand jury proceedings either need not be kept or are controlled by the prosecutor. ${ }^{73}$

The use of postindictment grand juror testimony concerning the prosecutor's conduct ${ }^{74}$ should be prohibited only if the interests pro-

69 For example, the prosecutor may make an inflammatory speech, or comment on the weight or sufficiency of the evidence immediately before or during the deliberations, when no witnesses are present.

70 Cf. Note, supra note 51 , at 323 n.68.

71 In these jurisdictions, the trial judge has discretion to decide whether or not to allow the defense attorney to interview grand jurors. See United States v. Smyth, 104 F. Supp. 279 (N.D. Cal. 1952). In that case, Judge Fee recognized that it was within the federal court's power to allow the defense attorney to examine grand jurors concerning the prosecutor's behavior, but he indicated that this power should be exercised rarely, if at all. This "traditional" reluctance to allow the defense attorney to interview grand jurors has severely curtailed the effectiveness of the undue influence doctrine even in jurisdictions that do not theoretically follow a rule of absolute secrecy. Cf. $8 \mathrm{~J}$. MOORE, FEDERAL. Practice f 6.04, at 6-46, 47 (2d ed. 1972).

72 E.g., People ex rel. Sears v. Romiti, 50 Ill. 2d 51, 277 N.E.2d 705 (1971), cert. denied, 406 U.S. 921 (1972).

73 D. MERNITZ, supra note $33, \S 3: 4$. It is not mandatory for the federal prosecutor to keep a record of the proceedings; if a record is kept, the prosecutor may control which portions of the proceedings are recorded. Mernitz suggests "that a complete stenographic transcript be made regardless of the local practice." Id. at 3:4-3:5. But cf. People ex rel. Sears v. Romiti, 50 Ill. 2d 51, 67, 277 N.E.2d 705, 713 (1971) (Goldenhersh, J., dissenting), cert. denied, 406 U.S. 921 (1972), where it was alleged that the prosecutor frequently went off the record to make comments prejudicial to the defendants.

74 This discussion is limited to the postindictment stage of the proceedings. Apparently only one court has sanctioned preindictment grand juror testimony concerning prosecutorial behavior. In that case, People v. Sears, 49 Ill. 2d 14, 273 N.E.2d 380 (1971), the court stated that in certain circumstances it is within the trial judge's power to meet in camera 
tected by excluding such testimony clearly outweigh the need for full enforcement of the undue influence doctrine. Courts have justified the exclusionary rule on two grounds: secrecy in grand jury proceedings and judicial economy. The traditional justification relies on the general policy of grand jury secrecy and the interests that it protects. In Pittsburg Plate Glass $v$. United States, ${ }^{75} \mathrm{Mr}$. Justice Brennan set forth these interests:

(1) To prevent the accused from escaping before he is indicted and arrested or from tampering with the witnesses against him. (2) To prevent disclosure of derogatory information presented to the grand jury against an accused who has not been indicted. (3) To encourage complainants and witnesses to come before the grand jury and speak freely without fear that their testimony will be made public thereby subjecting them to possible discomfort or retaliation. (4) To encourage the grand jurors to engage in uninhibited investigation and deliberation by barring disclosure of their votes and comments during the proceedings.

While these reasons may support the secrecy of grand jury deliberations while in progress, ${ }^{76}$ most of them are not relevant to the question of postindictment testimony concerning the prosecutor's behavior. The accused who alleges undue influence is contesting an already damaging indictment; it cannot, therefore, be said that the policy is necessary to prevent his escape or protect his reputation. Since the court will be unconcerned with the evidence against the defendant except as it relates to the prosecutor's behavior, there is little or no danger of tampering with witnesses. Finally, testimony concerning the prosecutor's behavior rather than its effect on the grand jurors is unlikely to involve revelation of what the grand jurors or witnesses said or did in the grand jury room.

It is true that protection of grand jurors from harassment by defendants may be more difficult if defendants are allowed to solicit and adduce testimony on the question of undue influence. Some defendants may attempt to coerce the jurors into perjuring themselves by testifying to wrongful prosecutorial behavior that did not in fact occur. The danger of harassment of grand jurors may be less serious, however, than

with the grand jury during the proceedings to consider testimony relating to undue infuence. It is uncertain, however, whether this case has continuing vitality. See text at notes 82-87 infra. The courts have refrained from interrupting the proceedings to hear testimony on this question because, as long as the proceedings are kept secret prior to indictment, no tangible harm can be done to anyone until an indictment is wrongfully returned.

75360 U.S. 395, 405 (1959) (Brennan, J., dissenting).

76 The need for permanent grand jury secrecy is questioned in Calkins, Grand Jury Secrecy, 63 Mich. L. Rev. 455 (1965). 
proponents of the secrecy doctrine have recognized. ${ }^{77}$ The laws against jury tampering ${ }^{78}$ and the canons of professional ethics ${ }^{79}$ stand as strong deterrents to this type of pressure. In jurisdictions that do not follow the exclusionary rule, the courts have been able to control effectively the possibility of harassment by closely supervising the taking of grand juror testimony. ${ }^{80}$ And the experience of jurisdictions that allow petit jurors to testify as to "extraneous influences" on verdicts indicates that juror harassment may be a danger more apparent than real. ${ }^{81}$ In sum, when the potential for harassment of grand jurors is compared with the alternative of giving prosecutors almost unchecked control over the grand jury, it seems clear that the value of secrecy does not justify the exclusionary rule.

In People ex rel. Sears v. Romiti, ${ }^{82}$ the Supreme Court of Illinois justified the exclusionary rule on the ground of economy in judicial proceedings. The case arose after a special grand jury returned indictments charging the State's Attorney of Cook County and other law enforcement officials with obstructing justice in connection with the fatal shootings, in 1969, of Illinois Black Panther Party leaders. ${ }^{83}$ The defendants moved to quash the indictments, claiming that the special prosecutor had exerted undue influence, and offered sworn and unsworn statements of grand jurors to support their allegations. The trial judge thereupon ordered an open hearing to receive testimony of grand jurors solely on the question of undue influence. On motion of the special prosecutor for writs of prohibition and mandamus to bar the hearing and to vacate the order for a hearing, the supreme court indicated that the use of any grand juror affidavits should have been strictly forbidden, and ordered the trial judge to vacate the hearing order and to refrain from taking any action on the undue influence charge. ${ }^{84}$

77 It may be contended that phone calls and requests by defense lawyers to grand jurors to take testimony would violate former jurors' rights to privacy, but required testimony would not differ significantly from the duty to testify of any citizen who is an eyewitness to a crime or other misconduct.

78 See, e.g., 18 U.S.C. \& 1503 (1970).

79 See, e.g., ABA Comm. on Professional Ethics, Opinions, No. 319 (1967).

80 For an example of close court supervision of grand juror testimony, see United States v. Wells, 163 F. 313 (D. Idaho 1908).

81 Cf. Comment, Impeachment of Jury Verdicts, 25 U. Cur. L. REv. 360, 368-72 (1958). 8250 Ill. 2d 5I, 277 N.E.2d 705 (1971), cert. denied, 406 U.S. 921 (1972).

83 For a description of some of the procedural complexities that arose during the grand jury proceedings and a general background of the case, see People v. Sears, 49 IIl. 2d 14, 273 N.E.2d 380 (1971).

84 People ex rel. Sears v. Romiti, 50 III. 2d 51, 63, 277 N.E.2d 705, 711 (1971), cert. denied, 406 U.S. 921 (1972). 
The majority opinion indicates that the court was reacting, at least in part, to the almost two-year delay between the beginning of the investigation into the shootings and the order for an open hearing: ${ }^{85}$ The court's denial of full enforcement of the strict undue influence standards that it had reaffirmed only months before in a procedural appeal in the same case ${ }^{86}$ was based not on legal precedent, ${ }^{87}$ but on its conclusion that the benefits of enforcement did not outweigh the costs of administrative delay.

The court's conclusion is premised on two highly questionable assumptions. The first is that if the exclusionary rule were repudiated, the courts would be inundated with spurious and dilatory appeals by defendants seeking to avoid criminal trials. There seems to be little evidence to support this assumption. At least since the beginning of the twentieth century, the federal courts and several state courts have accepted grand juror testimony on the question of undue influence ${ }^{88}$ without generating a significant number of undue influence claims. ${ }^{89}$

The second assumption implicit in the Illinois court's judicial economy rationale is that full enforcement of the undue influence doctrine is unnecessary because the trial is adequate protection for a defendant who is wrongfully accused..$^{90}$ This assumption presents two major diffculties. First, subsequent acquittal by a petit jury cannot compensate the defendant for the damage in lost time, money, and reputation that

85 The court prefaced its opinion by describing the lengthy procedural delays that preceded this appeal and then stated that " $[\mathrm{t}]$ here has been an increasing tendency in criminal cases to try some person other than the defendant, and some issue other than his guilt." 50 III. $2 d$ at 55,277 N.E.2d at 707.

86 People v. Sears, 49 IIl. 2d 14, 273 N.E.2d 380 (1971). The court seems to have made an abrupt shift in the six months that separated the two cases. In People v. Sears, supra, the court sanctioned, in certain circumstances, the interruption of the grand jury proceedings to allow grand jurors to testify in camera concerning undue influence. See note 74 supra.

87 Although the court cited eight cases from other jurisdictions that reject the exclusionary rule, no Illinois case directly supporting the exclusionary rule was cited. People ex rel. Sears v. Romiti, 50 Ill. 2d 51, 64-67, 277 N.E.2d 705, 712-13 (1971) (Goldenhersh, J., dissenting), cert. denied, 406 U.S. 921 (1972).

88 United States v. Perlman, 247 F. 158 (S.D.N.Y. 1917); United States v. Wells, 163 F. 313 (D. Idaho 1908); United States v. Kilpatrick, 16 F. 765 (W.D.N.C. 1883); United States v. Farrington, 5 F. 343 (N.D.N.Y. 188I); State v. Will, 97 Iowa 58, 65 N.W. 1010 (1896); State v. Kifer, 186 La. 674, 173 So. 169 (1937); Attorney Gen. v. Pelletier, 240 Mass. 264, 134 N.E. 407 (1922); State v. Manney, 24 N.J. 571, 133 A.2d 313 (1957).

89 While jurisdictions that have liberalized their rules concerning impeachment of petit juror verdicts have experienced a marked increase in appeals, see Comment, note 81 supra, at 366-72, there has not been a noticeable increase in appeals based on undue influence in jurisdictions that have rejected the exclusionary rule.

90 Cf. Coppedge v. United States, 311 F.2d 128, 132 (D.C. Cir. 1962) (Burger, J.) rev'd on other grounds, 369 U.S. 438 (1963). 
results from indictment. And second, the assumption proves too much: if the petit jury affords the defendant adequate protection, the modern grand jury has no reason for being. Even if this is true, however, it would be singularly inappropriate for the courts, in the name of judicial economy, to assume away the need for the grand jury when, by statute or constitutional provision, the people and their representatives have reached the opposite conclusion.91 In sum, because vigorous enforcement of the undue influence doctrine may be the only way to prevent the grand jury from being a "rubber stamp" for the prosecutor, neither unwarranted fears of grand juror harassment nor questionable calculations of judicial economy should be allowed to hamper that enforcement.

2. Adverse Publicity Generated by the Prosecutor. The prosecutor may influence the grand jury by conduct outside, as well as inside, the courtroom, particularly by means of remarks to the news media concerning matters subject to grand jury investigation. Since grand jurors are allowed access to all sources of information throughout the investigation, ${ }^{92}$ statements made by the prosecutor outside the grand jury room, including those that would constitute undue influence if made in their presence, may reach the grand jurors through the media. Instead of proscribing statements to the media that would constitute undue influence if made directly to the grand jurors, the courts either have applied a less stringent test focusing on the extent to which the statements actually biased grand jurors, ${ }^{93}$ or have refused altogether to quash indictments on adverse publicity grounds. ${ }^{94}$

The United States Supreme Court's decision in Beck $v$. Washington ${ }^{95}$ is the leading authority for the use of an actual bias standard to determine the consequences of publicity concerning subjects of grand jury investigation. Unlike the undue influence doctrine, under which there is an irrebuttable presumption of bias when a prosecutor exceeds the bounds of propriety, ${ }^{96}$ and unlike the rule applied in petit jury cases, according to which a similar presumption arises once a certain level

91 The 1970 Illinois constitution contains exactly the same indictment requirement as the 1870 Illinois constitution. Compare ILL. Const. art. $1, \& 7$ (1970) with ILL. ConsT. art II, $\$ 8$ (1870). Although the Illinois General Assembly has the power to abolish this indictment requirement they have not chosen to exercise it.

92 United States v. Smyth, 104 F. Supp. 283, 296-98 (N.D. Cal. 1952).

93 See United States v. Sweig, 316 F. Supp. 1148, 1153 (S.D.N.Y. 1970), aff'd, 441 F.2d 114 (2d Cir.), cert. denied, 403 U.S. 932 (1971), and cases cited therein.

94 See People ex rel. Sears v. Romiti, 50 Ill. 2d 51, 62-69, 277 N.E.2d 705, 710-11 (1971), cert. denied, 406 U.S. 921 (1972), and cases cited therein.

95369 U.S. 541 (1962).

96 See text at note 58 supra. 
and character of adverse publicity is shown, ${ }^{97}$ the actual bias test requires the defendant to prove that, in fact, adverse publicity affected the grand juror's decision to indict. Under this test the level and character of the publicity is irrelevant. To show actual bias, the defendant would have to obtain testimony from grand jurors as to their reason for indicting. All jurisdictions, however, absolutely prohibit any examination of grand jurors for such information. ${ }^{98}$ As a result, the use of the actual bias standard provides, in practice, little more protection than does the rule in some jurisdictions that even actual bias resulting from publicity is not ground for quashing indictments. ${ }^{99}$ Indeed, courts that adhere to the latter rule often cite Beck as authority for avoiding even an inquiry into actual bias since the Beck court, having found no evidence of actual bias in the case before it, refused to reach the question whether the states are constitutionally required to provide unbiased grand juries. ${ }^{100}$

The failure of the courts to protect against the effects of adverse publicity on the grand jury has been justified on several grounds. Because the grand jury has always been allowed to indict on the basis of hearsay, it has been argued that to prevent the grand jury from relying on information publicized by the news media would be unreasonable: that just as reliance on hearsay is allowed in order to insure the grand jury's effectiveness as an investigative body, so also the grand jury should be allowed to rely on information derived from the media. ${ }^{101} \mathrm{It}$ has also been argued that the costs of impanelling a new grand jury when publicity is presumed to have affected the old, or of shielding the grand jury from publicity concerning the subject of its investigation, are prohibitive, ${ }^{102}$ and that subsequent trial by a petit jury affords sufficient protection to the indictee. Finally, because there can be no change of venue for grand jury proceedings, a new indictment free from the presumed effects of adverse publicity would be difficult to obtain..$^{103}$

These arguments are of questionable validity. Even though the sources of information available to grand juries have never been as

97 See Sheppard v. Maxwell, 384 U.S. 333, 351-52 (1966).

88 See Calkins, supra note 76, at 459 .

99 Although the federal courts have followed the "actual bias" test since Beck, in no case has the application of the test resulted in the quashing of an indictment. Bartlett, Defendant's Right to an Unbiased Federal Grand Jury, 47 B.U.L. REv. 551, 559, 562 (1967).

100 People ex rel. Sears v. Romiti, 50 IIl. 2d 51, 62, 277 N.E.2d 705, 710 (1971), cert. denied, 406 U.S. 921 (1972).

101 See Bartlett, supra note 99, at 559.

102 See Commonwealth v. Monahan, 349 Mass. 139, 154-56, 207 N.E.2d 29, 39-40 (1965). 103 People ex rel. Sears v. Romiti, 50 Ill. 2d 51, 62, 277 N.E.2d 705, 710 (1971), cert. denied, 406 U.S. 921 (1972). 
restricted as in the petit jury context, and grand jurors must often weigh the probative value of hearsay evidence, grand jurors are, nonetheless, as likely as petit jurors to have difficulty making a detached decision when faced with a "carnival atmosphere of publicity."104 While protection against bias may increase administrative costs-an argument equally applicable to all criminal procedural safeguards-there is no objective basis for concluding that the added costs exceed the value of preserving the independent functioning of the grand jury in determining probable cause. In addition, the nonavailability of a change of venue has little significance: even in the petit jury context, a change of venue in a widely publicized case may often be insufficient to counteract the prejudicial effect of publicity. ${ }^{105}$

However one balances the considerations favoring and opposing the courts' present treatment of publicity in general, the reluctance to quash indictments on the basis of adverse publicity has the most serious consequences when the prosecutor is the source of the adverse publicity. Indeed, the Beck case, which has become the primary precedent for the restrictive approach to quashing indictments that might be tainted by publicity, involved publicity that was not connected with the prosecutor's office. ${ }^{106}$ It has long been recognized that there is a qualitative difference between the effect of the prosecutor's statements to the grand jury and the effect of statements by other members of society. ${ }^{107}$ While the prosecutor has always been strictly limited in his direct statements, the courts have been extremely careful to keep open all other lines of communication to the grand jurors.

A few courts have explicitly recognized the need to distinguish between adverse publicity emanating from the prosecutor's office and other adverse publicity. ${ }^{108}$ In United States $v$. Sweig, ${ }^{109}$ in response to a motion to quash on the basis of adverse publicity, much of which was

104 Cf. Sheppard v. Maxwell, 384 U.S. 333, 358 (1966). Bartlett, supra note 99, at 565, argues that the Sheppard rule should be extended to the grand jury when, because of publicity, a carnival atmosphere surrounds the proceedings.

105 Cf. Estes v. Texas, 381 U.S. 532, 535 (1965).

106 The publicity in Beck was generated by a Senate committee investigating possible criminal activities of Teamster Union officials. Beck v. Washington, 369 U.S. 541, 546-49 (1962).

107 See text and notes at notes 24-40 \& 57-91 supra.

108 See Silverthorne v. United States, 400 F.2d 627, 633-34 (9th Gir. 1968), aff'd after retrial, 430 F.2d 675 (9th Cir. 1970), cert. denied, 400 U.S. 1022 (1971); United States v. Nunan, 236 F.2d 576, 593 (2d Cir. 1956), cert. denied, 353 U.S. 912 (1957); United States v. Sweig, 316 F. Supp. 1148, 1158-55 (S.D.N.Y. 1970), aff'd, 441 F.2d 114 (2d Cir.), cert. denied, 403 U.S. 932 (1971); United States v. Kahaner, 204 F. Supp. 921, 922 (S.D.N.Y. 1962), aff'd, 317 F.2d 459 (2d Cir.), cert. denied, 375 U.S. 836 (1963).

109316 F. Supp. 1148, 1153 (S.D.N.Y. 1970), aff'd, 441 F.2d 114 (2d Gir.), cert. denied, 403 U.S. 932 (1971). 
alleged to have been "generated by the Department of Justice itself," Judge Frankel stated:

Unless the role of the grand jury as a shield for the citizen as well as a prosecutorial agency is to become an empty slogan, there are kinds of pressure that must obviously be avoided to the extent possible. However free may be sources of "fact" the generation of public animus against a prospective defendant, with the attendant danger that grand jurors may be subjected to subtle or explicit demands of the prosecution, ... is no part of the prosecution's legitimate business. ${ }^{110}$

The approach of the court in Sweig is sound as a matter of logic. Greater demands of fairness should be placed on officers of the court than on those who are in the business of purveying the news. And in focusing on prosecutorial conduct, Judge Frankel directed his analysis to objectively ascertainable evidence-as in the undue influence casesrather than to the subjective elements that may influence grand juror behavior.

Sweig's value as a precedent is lessened, however, by the use of bias rather than undue influence as the touchstone for the decision and the court's holding that the evidence was insufficient to link the adverse publicity to the prosecutor's office. ${ }^{111}$ Yet the thrust of the Sweig opinion is that grand juries should be independent of improper statements by the prosecutor whether they are made directly to the grand jury or reach the grand jurors through the media.

The best way to reach all such statements would be to extend the undue influence doctrine to reach public communications. The undue influence doctrine provides solid precedent for limiting the prosecutor's behavior affecting grand jury proceedings. It defines clearly the permissible range of prosecutorial statements concerning targets of investigation. It would permit the prosecutor to inform the public as to the general nature of the investigation and the identity of individuals under investigation, but would bar him from issuing inflammatory or tendentious statements concerning them. ${ }^{112}$ Moreover, applying the undue influence analysis to these cases by allowing an irrebuttable presumption of bias if the standards of conduct were breached would not

$110 \mathrm{Id}$. at 1153.

111 See id. at $1153-55$.

112 The prosecutor may serve the public interest by announcing the general scope of the investigation and by naming particular individuals under investigation, but he does not serve the public by attempting to use the press as a tool to influence the grand jury. Recognizing this, the Second Circuit has adopted strict rules to limit the prosecutor's statements to the media prior to or during a grand jury investigation. Id. at 1154 . 
entail an inquiry into the grand jurors' thoughts. Finally, it would serve to bolster the policies of the traditional undue influence doctrine by forbidding the prosecutor to do indirectly that which he is currently forbidden to do directly.

In extending the undue influence doctrine beyond those situations in which the prosecutor was actually present before the grand jury, two problems must be confronted. The first concerns identification of the prosecutor's office as the source of the prohibited statements. Of course, if the prosecutor or his staff is quoted or otherwise directly identified in the media as the source of the statements, the court will have no significant difficulty applying the doctrine. The problem would arise if a defendant claimed that adverse publicity identified in the media as coming from "official sources," or the like, was, in fact, generated by the prosecutor's office.

Although the public has an interest in insuring that the prosecutor will not use the "official source" label as a shield for improper behavior, that interest does not justify an inquiry into the actual source of the publicity. Official source statements do not have the weight and prestige of the prosecutor's office and thus are indistinguishable from other sources of grand jury information that have never been censored or limited by the undue influence doctrine. In addition to the fact that the official source is analytically outside the scope of the undue influence doctrine, there would be practical difficulties in taking evidence to show a link to the prosecutor's office. Inquiry into the newspaperman's sources would raise serious first amendment problems. ${ }^{113}$ Moreover, if the prosecutor were required to answer for every official source statement in the media, he would be saddled with an intolerable burden. In applying the undue influence doctrine to adverse publicity, therefore, it seems better policy for the courts to limit their consideration to statements that are directly linked to the prosecutor's office at the time they are made.

The second problem in extending the undue influence doctrine beyond situations in which the prosecutor was actually present before the grand jury concerns the determination whether the grand jury had access to the prosecutor's statements published in the media. Since the statements would have been made outside the grand jury room, there could be no immediate certainty that the grand jurors had knowledge of them. The courts would therefore have to decide whether: (1) to require the defendant to prove that the grand jurors knew of the

113 See Branzburg v. Hayes, 408 U.S. 665, 707-08 (1972); cf. In re Grand Jury, January 1969, 315 F. Supp. 662 (D. Md. 1970). 
improper statements; (2) to presume that they had access to the statements but allow the prosecutor to rebut that presumption; or (3) to impute knowledge of the improper behavior to the grand jurors as an irrebuttable presumption.

Although there is some merit in each of these approaches, the second alternative seems the most reasonable in light of the interests involved. Placing the burden of proof on the defendant, although a traditional approach to affirmative defenses, might entail an expensive and timeconsuming procedure that would significantly lessen the deterrent power of the undue influence doctrine. Creating an irrebuttable presumption of knowledge of the improper statements, while it might have a greater deterrent effect on the prosecutor, would needlessly require reindictment in cases where, in fact, no juror was aware of the statements. By creating a rebuttable presumption of grand juror knowledge, however, the independence of the grand jury could be protected without the needless expense that an irrebuttable presumption would entail.

B. The Trial Judge

The inquiry into the trial judge's behavior has been similar to the undue influence analysis used to test the prosecutor's direct statements to the grand jury. The cases that concern the trial judge's direct relationship with the grand jury involve allegations that his behavior has impaired the ability of the grand jury to make an independent determination of probable cause.

Appellate courts have quashed indictments when the trial judge has stated or implied to the grand jury that a particular defendant is guilty. In Blau v. State, ${ }^{114}$ the Mississippi Supreme Court held that where a grand jury had originally voted a "no bill" but changed its vote to a "true bill" after the trial judge indicated he believed that the defendants had violated the law, the indictments must be quashed on undue influence grounds. Similarly, in Blake $v$. State, ${ }^{115}$ where a trial judge referred to individuals by name several times in his original charge, and later discharged three members of the grand jury who refused to indict them, the Criminal Court of Appeals of Oklahoma held that the indictment returned against the named individuals should be quashed. In People v. Both, ${ }^{110}$ the Supreme Court of New York extended the principle developed in the earlier cases. The indictment in Both had been voted by a grand jury after the trial judge had stated that he thought there was sufficient evidence to indict particular defendants. 
The New York Supreme Court quashed the indictment even though the trial judge explicitly told the grand jury that he was not advising them to indict anyone.

Although the thrust of the undue influence inquiry is the same when applied to the judge as when applied to the prosecutor, there has been considerably less difficulty in enforcing the doctrine when the judge's conduct has been questioned. First, the trial judge, unlike the prosecutor, ordinarily has no special interest in obtaining indictments against particular individuals. ${ }^{117}$ Second, and perhaps more important, the trial judge is barred from the grand jury room and, in almost all jurisdictions, his presence in the room is considered a per se violation of the undue influence doctrine. ${ }^{118}$ This rule significantly reduces the ability of the trial judge to force his opinions on the grand jurors and insures that his only contact with the grand jurors is a matter of public record available for the scrutiny of the defense attorneys and the appellate courts. A final reason for the relative ease of enforcement is that in cases in which the trial judge has intruded upon the secrecy of the grand jury room, the courts have accepted the testimony of grand jurors to prove judicial misbehavior. ${ }^{119}$ Taken together, the rule against the trial judge's entrance into the grand jury room and the limits placed on his ability to single out individuals for indictment provide an effective safeguard against undue influence by the trial judge.

\section{Conclusion}

The grand jury exists to protect individual citizens from oppression by the state. The major danger inherent in the system is that it may easily be converted into a tool of prosecutorial oppression if the prosecutor and the trial judge do not conform their behavior to the standards of procedural fairness evolved by the appellate courts. Although these standards seem adequate to control prosecutorial behavior, several jurisdictions have severely reduced their effectiveness by excluding evidence of prosecutorial misbehavior and by refusing to extend the protections of the undue influence doctrine to the prosecutor's public statements.

117 This may not be true in those states that give the trial judge authority to conduct what has been termed a "one-man grand jury" investigation. In these states, Connecticut and Michigan, the trial judge is authorized to conduct in camera investigations into crime and make his own determination as to probable cause. It has been charged that politically motivated judges have used this device for personal aggrandizement rather than to further the cause of justice. For a discussion of the one-man grand jury, see In re Oliver, 333 U.S. 257 (1948); Salvaggio v. Cotter, 324 F. Supp. 681 (D. Conn.) aff'd, 447 F.2d 1406 (2d Cir. 1971); R. Scigliano, The Michigan One-Man Grand Jury (1957).

118 See, e.g., Hammers v. State, 337 P.2d 1097, 1109-11 (Okla. Crim. App. 1959).

119 E.g., State v. Will, 97 Iowa 58, 65 N.W. 1010 (1896). 
To protect the major remaining function of the modern grand jurymaking an independent determination of probable cause for bringing suspects to trial-the grand jurors must be shielded from overbearing influence by the prosecutor. The undue influence doctrine requires that indictments be quashed when the prosecutor behaves in a manner that is presumed to influence the grand jurors' evaluation of the facts. This doctrine is well adapted to protect the independence of the grand jury's investigation from the prosecutor. Two changes in the court's application of the doctrine are necessary, however, to make it truly effective. First, the grand jurors should be allowed to testify to acts of the prosecutor that may constitute undue influence. And second, the doctrine should be extended to the prosecutor's public statements, which may undermine grand jury independence to the same extent as direct statements to the grand jurors. 